Nebojša Paunković, Džejn Paunković ${ }^{1}$

\title{
AUTOIMUNA TIREOIDNA STIMULACIJA - POVODOM 60 GODINA OTKRIĆA LATS-a
}

\begin{abstract}
Sažetak: Prikazali smo aktivnosti koje su obavljali mnogi istraživači a koje su se odnosile na autoimunu tireoidnu stimulaciju. Iste su počele pre 60 -ak godina i traju i danas. Prikazali smo i naše rezultate na ovom planu, od ranih pokušaja testiranja LATS-a, preko razvoja TBI testova, razvoja testa za merenje generacije cAMP u suspenziji tireocita, pa do kliničke primene.

Abstract: Authors are presenting activities of numerous investigators in the field of autoimmune thyroid stimulation. Although, interest in this field commenced some 60 years ago, it is still enthusiastic and challenging. We have presented some our results, from the early attempts in LATS testing, through development of TBI tests, introduction of method for measurement of cAMP generation in thyrocytes suspension, including the clinical application.
\end{abstract}

\section{UVOD}

U fiziološkim uslovima, štitasta žlezda stimulisana je tireotropnim hormonom adenohipofize. Intaktnost funkcionisanja hipotalamo-hipofizo-tireoidne osovine najbolji je dokaz eutireoidnog stanja.

U autoimunoj hipertireozi (Graves-Bazedovljeva bolest) štitasta žlezda je pod uticajem „patoloških stimulatora”. Otkrićem humoralnog stimulatora „dugog dejstva" (Long Acting Thyroid Stimulator - LATS) od strane Adamsa i Purvesa, 1956 (1) započeta je era razumevanja etiologije autoimune hipertireoze. Identifikovanje prirode LATS-a (2), razumevanje njegovog delovanja na receptore za TSH tireocita (3), povezivanje ove „humoralne” stimulacije sa celularnim imunitetom $(4,5)$, dovelo je do značajnog razjašnjenja etiopatogeneze ove bolesti, ali i do razvoja niza metoda i postupaka za detekciju ove stimulacije $(6,7,8,9,10)$.

$\mathrm{U}$ načelu, testovi za procenu autoimune tireoidne stimulacije mogli bi da se svrstaju u dve grupe:

- direktno dokazivanje ove stimulacije u serumu obolelih merenjem efekata in vivo ili in vitro koje ona izaziva:

1 Poliklinika „Paunković”, Zaječar, npaunkovic@sezampro.rs 
- testiranje LATS-a,

- merenje generacije cAMP u tireocitima;

- indirektno dokazivanje tireostimulantnih autoantitela (TSAb) radioreceptorskim testom.

\section{Metode i rezultati}

\section{Merenje stimulatornog učinka antitela na TSH receptore (biološki testovi)}

\section{a) Testiranje LATS-a}

Ranih sedamdesetih godina i mi smo pokušali da razvijemo metodu za dokazivanje LATS-a (11). U to vreme, a i kasnije, u našoj zemlji metodu su primenjivali samo istraživači iz jedne institucije (12). Isti autor (Karanfilski) je vrlo lepo izložio istorijat otkrića LATS-a (Beograd, 2006). Metodu smo izvodili na osnovu McKenzie-evog ogleda na miševima (6), uz maksimalne improvizacije (zamena komercijalne niskojodne dijete hranjenjem eksperimentalnih životinja ječmom iz jodoprivnih terena, korišćenje rastvorenih tableta tiroksina za injekcionu aplikaciju miševima, merenje radioaktivnosti u improvizovanom brojaču itd). Mada je metoda bila vrlo zametna a mi neiskusni eksperimentatori, dobili smo zadovoljavajuće i reproducibilne rezultate. Metodu iz brojnih organizacionih i tehničkih razloga nismo dalje primenjivali, a rezultate $u$ to vreme nismo nigde publikovali smatrajući da je broj testiranih bolesnika mali.

\section{b) Stimulacija generisanja cAMP u tireocitima in vitro}

Kao i kod većine drugih membranskih receptora, nakon stimulacije agonističkim hormonom, generiše se kao „,second messanger” ciklični AMP. Na ovom efektu zasniva se testiranje delovanja tireostimulantnih autoantitela (TSAb) na isečke tireoidnog tkiva ili, još bolje, na izolovanje tireocit $u$ in vitro sistemu $(13,14,15)$.

Poslednje dekade dvadesetog veka razvili smo metodu koja se ukratko sastoji u sledećem: iz tek zaklanih svinja vadi se tireoideja i iz nje se kolagenaznom digestijom izdvajaju tireociti u suspenziji (u modifikovanom Henksovom puferu). Tireostimulantna antitela se određuju iz globulinske frakcije ispitivanog seruma bolesnika (dobijene taloženjem PEG-om) koja se inkubira sa prethodno pripremljenom tireocitnom suspenzijom. Odgovarajućim RIA određuje se novonastala koncentracija cAMP, koja je merilo tireostimulirajuće aktivnosti. Detalji metode se mogu naći na drugom mestu $(13,16)$. Ovaj sistem reaguje na dodate „tireostimulantne supstance” (bovini TSH, B.65/122 standard), ali i na prisutna TSAb u serumu.

Rezultate naših prvih ispitivanja prikazali smo na donjoj tabeli (slika II 2.12). 
Slika II 2.12. Uticaj seruma obolelih od Graves-ove bolesti i ydravih osoba na stvaranje cAMP

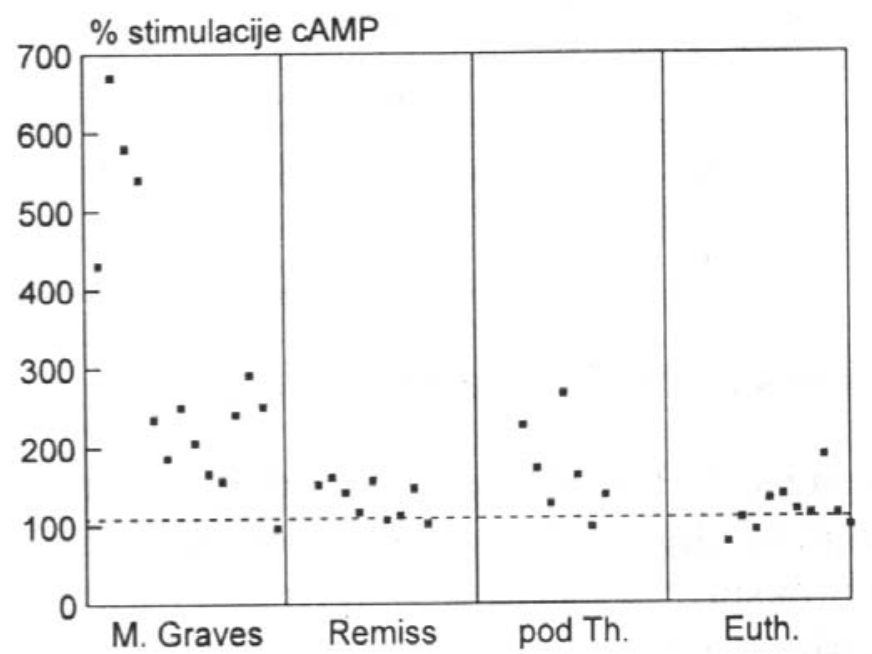

Razvoj metode za dokazivanje generacije cAMP u suspenziji tireocita (Jane Paunkovic, 1993) dovela je do posle doktorskog usavršavanja u Univerzitetskoj klinici u Kyotu, odnosno do vrlo plodne saradnje sa Kasagijem, Konichi-jem i drugim kolegama. U toku kraćeg boravka u kompaniji Otsuka u Tokushimi demonstrirana nam je metoda Kasagija za produkciju kulture tkiva, odnosno ćelija iz svinjske tireoideje, na industrijski način, za više hiljada uzoraka.

Nekoliko poslednjih dana boravka u Kyotu posvetili smo uhodavanju iste metode, ali na FRTL5 ćelijama (17). Imali smo priliku da upoznamo Leonarda Kohn-a, i da lično od njega dobijemo klon pomenutih ćelija, koje smo uspeli da prenesemo do Srbije.

\section{Dokazivanje autoantitela na TSH receptore radioreceptorskim testom}

Smith i Hall 1974. osmislili su in vitro test (kompetitivni radioreceptorski test) - TBI (thyrotropin binding inhibition) (7). Njime se dokazivao imunoglobulin koji

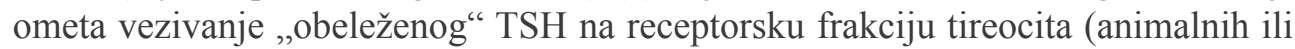
humanih) in vitro - TBII (thyrotropin binding inhibition imunoglobulin).

Membranska frakcija tireocita (čoveka ili nekih životinja) može da posluži kao bogat izvor receptora za tireotropin (TSH-R). Ako se ovoj frakciji doda specifičan „obeleženi” ligand ( ${ }^{125} \mathrm{I}$ TSH), njegovo vezivanje može da se inhibira neobeleženim ligandom (endogenim ili egzogeno dodatim TSH), ali i autoantitelima koja se vezuju na TSH-R. Ova inhibicija biće u srazmeri sa koncentracijom autoantitela koja se na taj način mogu detektovati. 
Počeli smo ovim pitanjem da se bavimo 1984. godine. Pokušali smo da razvijemo testove sa sopstvenim komponentama. Iz štitnjača svinja izdvajali smo tireocite, rastvarali ih u lubrolu (deterdžentu), a kao neradioaktivnu inhibitornu komponentu koristili smo Ambinon, preparat sa tireotropnim delovanjem. Ove dve komponente u radioreceptorskom testu praktično smo osvojili (grafikon 1 i 2). Međutim, teškoće su nastale kod obeleženog TSH. Preparacija koja se koristila u RIA postupku, budući da je bila samo imunološki (ne i biološki) aktivna, nije bila podesna za receptorski test (18).

Grafikon 1. Radioreceptorski test za tireotropin: testiranje membranskih preparacija

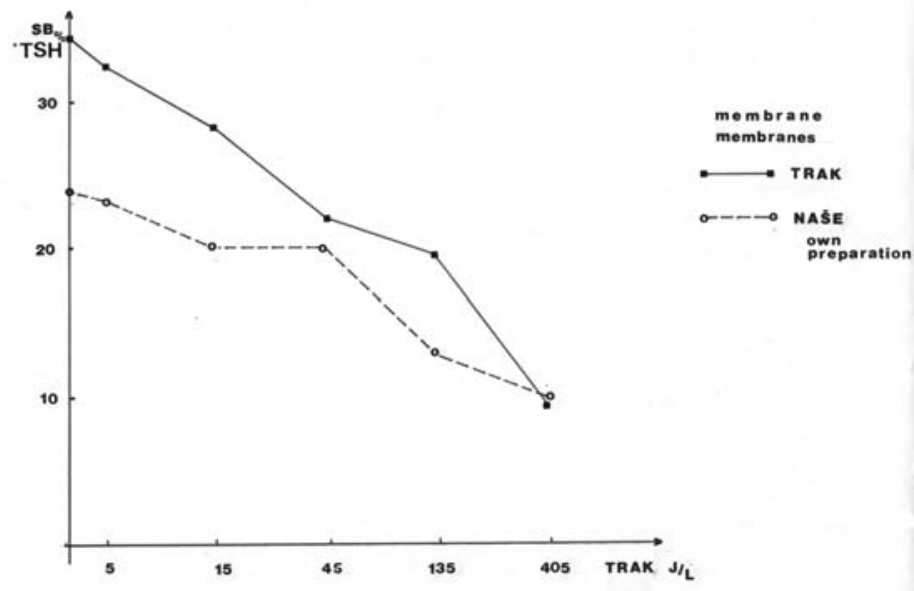

Grafikon 2. Radioreceptorski test za tireotropin: testiranje neobeleženog hormona

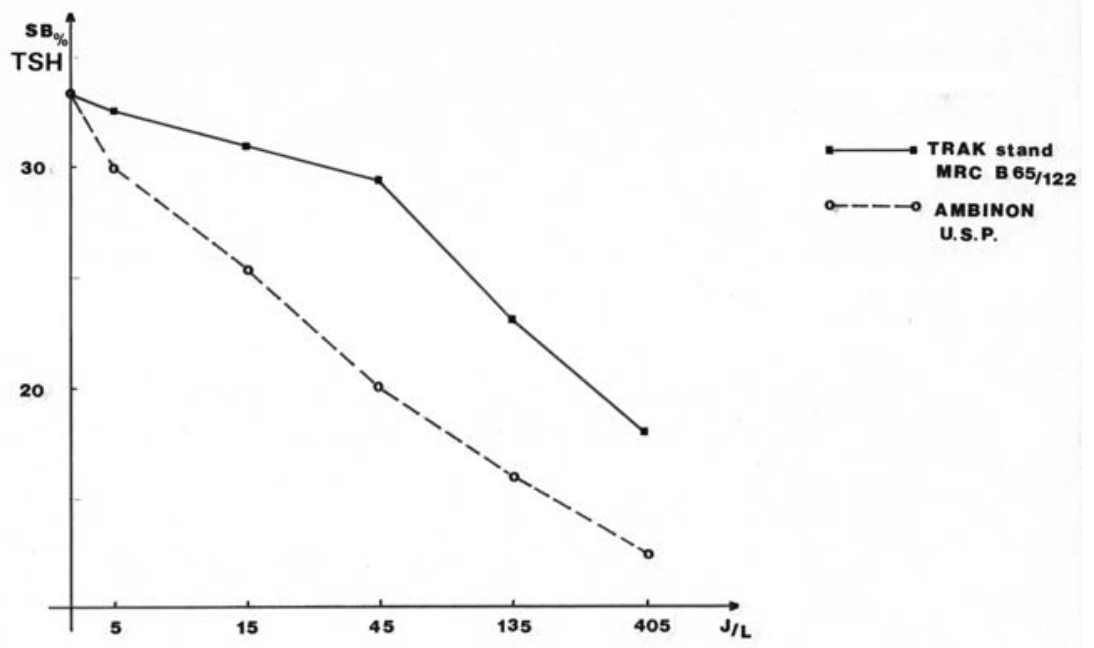


Danas postoje vrlo kvalitetni (i skupi) komercijalni kompleti za izvođenje ovog radioreceptorskog testa. TRAK-assay, BRAHMs, Germany, kao receptorsku komponentu koristi humane TSH receptore, dobijene genetskim inžinjeringom (transfektovane u leukemijsku ćelijsku liniju K562, Costagliola,1999) (19), naknadno liofilizirane i vezane na plastično dno epruveta, kao radioaktivnu preparaciju jako dobar obeleženi bovini TSH za receptorske studije (,receptor grade”) a kao neaktivnu komponentu (,standarde”) humane serume sa visokim koncentracijama TRAb-a (20).

Humani TRAK-assay znatno je senzitivniji od prethodno korišćenog eseja (sa svinjskim membranama). Uradili smo ispitivanje dijagnostičke senzitivosti (stvarno pozitivni nelečeni bolesnici) kod 356 nelečenih bolesnika od Basedow-ljeve bolesti za TRAK assay, i 111 odgovarajućih pacijenata za TRAK assay human). Nalazi: za TRAk assay $85 \%$ a za TRAK human $97.5 \%$. Uporedno određivanje TRAb-a kod 130 bolesnika sa hipertireozom i 60 nelečenih bolesnika (novootkrivenih) sa Graves-Bazedovljevom bolešću (graf. 3), korelacija je bila dobra (21).

Graph 3. A. Correlation between TRAK-assay and TRAK Dyno human findings in 130 patients with hyperthyroidism B. Correlation between TRAK-assay and TRAK Dyno human results in 60 untreated patients with Graves' disease.

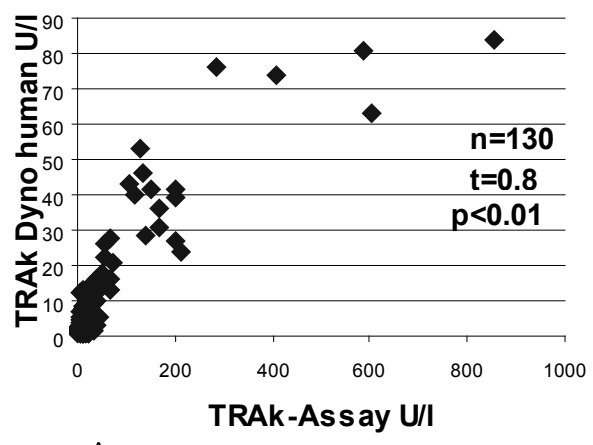

A

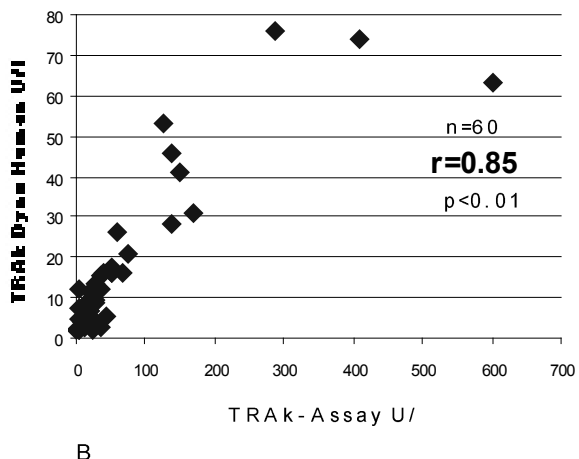

B

Posle ovog prikaza razvoja metoda za dokazivanje tireoidne stimulacije (i našeg rada na tom polju), u kraćem izlaganju navodimo i naše rezultate.

Od 1984. do danas, uradili smo ukupno oko 5200 TBII testova (4300 u laboratoriji Službe za nuklearnu medicinu i 900 u poliklinici „Paunković”). Koristili smo TRAK-assay prvo firme Henning, kasnije BRAHMs, iz Berlina. Do 2001. koristili smo „stari”, konvencionalni komplet sa svinjskim membranama, a posle tog roka TRAK-assay dyno, human.

Antitela na TSH receptore koristili smo u dijagnozi imunogene hipertireoze (i diferencijalnoj dijagnozi), praćenju toka bolesti (ulazak u remisiju, diferentovanje „respondera i non-respondera) i najavu recidiva bolesti. Mislimo da je bio naš realan 
doprinos ovom pitanju i zapažanje istovremene pojave imunogene i neimunogene hipertireoze (22).

Kod bolesnika lečenih medikamentno proverili smo još jedanput naša prethodna zapažanja. I ovaj put, oko 2/3 bolesnika su „,responderi” (grafikon 4). Posebno ističemo da su i bolesnici lečeni u našoj privatnoj poliklinici i da su uzorci seruma obrađivani u laboratoriji koja je u sastavu poliklinike. Korišćeni su, kao i ranije, reagensi firme Termo (Brahms) za određivanje TRAb, odnosno firme Walac (TSH ultra i FT4).

Grafikon 4. Kontinuirano praćenje TRAb u toku medikamentne terapije na 2 meseca kod 25 bolesnika - responderi i neresponderi

TRAb follow-up

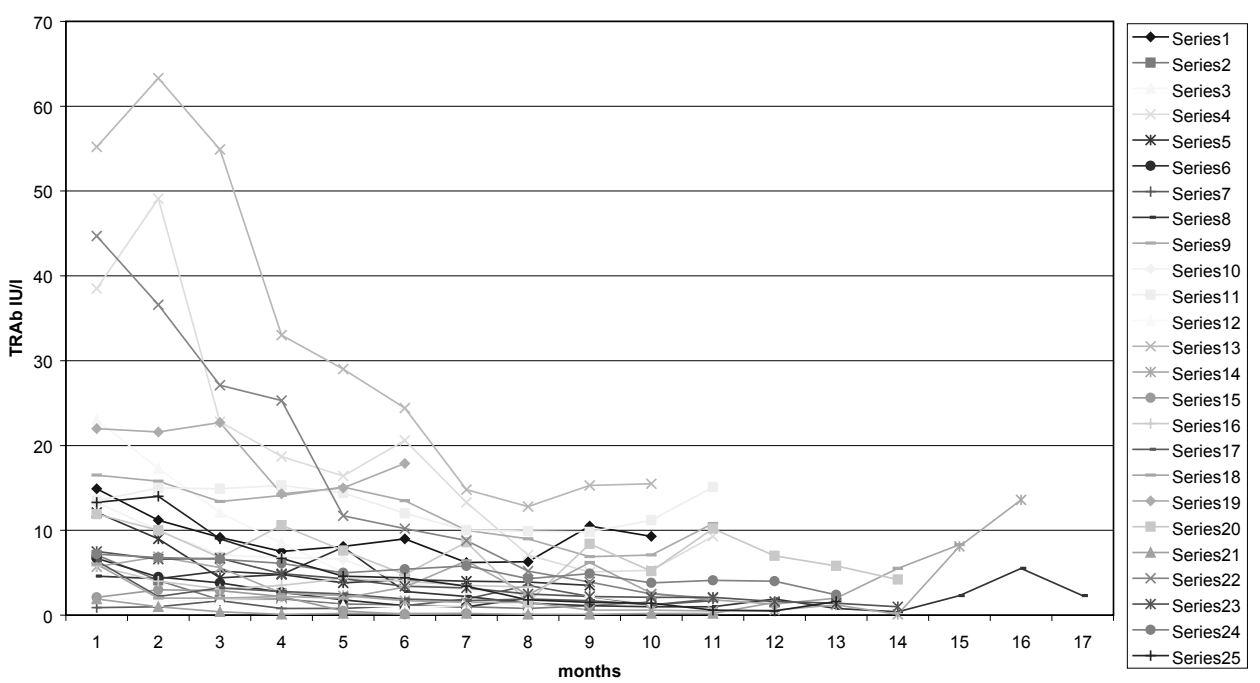

Ovi receptorski testovi su danas znatno modifikovani, koriste se neradioaktivni obeleživači (luminescentni,obeleženi derivatima akridina, enzimski), testovi su prilagođeni računarskoj tehnici, itd (23). Imali smo prilike da koristimo i usluge jedne od beogradskih privatnih laboratorija, u njoj je urađeno 77 uzoraka, ali o korišćenoj metodi nemamo dosta informacija (elektro hemiluminiscentni immunoassay, rađeno na Cobas analyzeru, reagensi firme Roche), a ni saglasnost laboratorije o iznošenju rezultata.

\section{DISKUSIJA}

Zapažanje dva novozelandska istraživača, Adamsa i Purvesa,1956. godine, da u serumu obolelih od Graves-Basedow-ljeve bolesti postoji neka materija koja se po 
dužini i trajanju delovanja razlikuje od hipofiznog TSH, pokrenula su pravu lavinu saznanja iz oblasti endokrinologije, imunologije i drugih nauka. Pojavile su se prve modifikacije tehnika za dokazivanje LATS-a (McKenzie, et. al., 1958). Napravljen je i alternativni pristup, radioreceptorski test za dokazivanje imunoglobulina, koji ometaju vezivanje TSH, odnosno tireostimulantnih imunoglobulina od strane Smith-a i Hall-a, 1974.

Postepeno se izmenio i klinički aksiom da je Basedovljeva bolest izazvana hipersekrecijom hipofiznog TSH, tj. da tzv. ,sekundarna hipertireoza“" ne postoji. Mada je LATS opisan 1956, a posle prvog izveštaja bilo je još puno radova iz te oblasti, u domaćoj literaturi se ova pitanja uopšte ne pominju (24). Još uvek se na jednoj od beogradskih endokrinoloških klinika u terapiji hipertireoze davao zasićen rastvor kalijum jodida, jer ,jodidi deluju inhibitorno na lučenje TSH i time smanjuju njegovu preveliku stimulaciju tireoideje" (24, str 94). Trebalo je u toj situaciji biti vrlo oprezan, pogotovu što su i prvi pokušaji detekcije LATS-a poticali od jednog specijalizanta iz „unutrašnjosti“, rađeni u podrumu klinike na kojoj se LATS nije pominjao (11).

Naša dalja istraživanja na polju tireoidne stimulacije nastavljena su u daleko povoljnijoj klimi (Nuklearna medicina Zaječar), uz uvođenje novog saradnika, Džejn Miladinović, kasnije Paunković). Rezultati su bili očiti, od razvoja novih dijagnostičkih metoda, do uspostavljanja kontakata i saradnje sa brojnim istraživačima iz sveta.

\section{Literatura}

1. Adams D.D., Purves H.D. Abnormal responces in the assay of thyrotropin. Proc Univ Otago Med Sch 1956, 34:11.

2. Kriss J.P., Pleshakov V., Chien J.R. Isolation and identification of the long acting thyroid stimulator and its relation to hyperthyroidism and circumscribed pretibial myxedema. J Clin Endocrinol Metab 1964, 24:1005.

3. Smith B.R., Ricards C.R., Davies J.E., et al. The thyrotropin receptor and its role in Graves' disease. J Endocrinol Invest 1985, 8:175.

4. Zakarija M., McKenzie J.M., Clafin A. Humoral aspects of Graves' disease, In: Walfish P.G., Wall J.R., Wolpe R. Autoimmunity and the thyroid. Academic Press, Toronto, 1985,109 .

5. Volpe R. The aetiology of thyroid disease. In: Rational Diagnosis of Thyroid disease, Verlag H. Egermann, Vienna, 1977, 9-41.

6. McKenzie J.M. Delayed thyroid responce to serum from thyrotoxic patients. Endocrinology, 1958, 62:865.

7. Smith B.R., Hall R. Thyroid-stimulating immunoglobulines in Graves' disease. Lancet, 1974, 2:427.

8. Onaya T., Kotani M., Yamada T., Ochi Y. New in vitro test to detect the thyroid stimulator in sera from hyperthyroid patients by measuring colloid droplet formation and cyclic AMP in human thyroid slices. J Clin Endocrinol Metab 1973, 36:859. 
9. Rapoport B, Greenspan S, Foletti S, Pepitone M. Clinical experience with a human thyroid cell bioassay for thyroid stimulating immunoglobulin. J Clin Endocrinol Metab 1984; 58:332.

10. Kasagi K., Iida Y., Konishi J., et al. Human thyroid stimulator (HTS) assay using cultured human thyroid cells. 6th International Congress of Endocrinology, Melbourne 1980, 210 .

11. Adanja G., Paunkovic N. Razvoj metode za testiranje LATS-a, Beograd, 1974, nepublikovani radovi.

12. Karanfilski B., et al. Naša prva iskustva u testiranju LATS-a. XI jugoslovenski sastanak za nuklearnu medicinu, Budva, 1971.

13. Paunković Dž. Izučavanje postreceptorskih događaja u kulturi tireocita in vitro nakon stimulacije receptora za tireotropin. Doktorska disertacija, Beograd, 1993.

14. Marcocci C., Valente W.A., Pinchera A., et al. Graves' IgG stimulation of iodide uptake in FRTL-5 rat thyroid cells: a clinical assay complementing FRTL-5 assay measuring adenylate cyclase and grotw-stimulating antibodies in autoimmune thyroid disease. $\mathrm{J}$ Endocrinol Invest 1983, 6:463.

15. Zakarija M., McKenzie J.M. Variations in the culture medium for FRTL-5 cells: effects on growth and iodine uptake. Endocrinology 1989, 125:1253.

16. Paunković J.,Paunković N., Nikolić K. Procena autoimune stimulacije štitaste žlezde merenjem nastanka cAMP u suspenziji tireocita. V kongres endokrinologa Jugoslavije, Beograd, 1993.

17. Valente WA, Vitti P, Rotella CM, Vaughan MM, Aloj SM,Grollman EF, Ambesi-Impiombato FS, Kohn LD,Antibodies that promote thyroid growth: a distinctpopulation of thyroid stimulating autoantibodies. N EngJ Med 309: 1028 (1983).

18. Paunkovic N., Miladinovic J., Nikolic K. Radioreceptorski test za tireotropin: priprema i testiranje komponenti. Jugoslovenski sastanak za nuklearnu Radiol Iugosl 1989; 23: 383-386.

19. Costagliola S, Morgenthaler NG, Hoermann R, Badenhoop K, Struck J, Freitag D, Poertl S, Weglohner W, Hollidt JM, Quadbeck B, Dumont JE, Schumm-Draeger PM, Bergmann A, Mann K, Vassart G, Usadel KH, 1999, Second generation assay for thyrotropin receptor antibodies has superior diagnostic sensitivity for Graves' disease. J Clin Endocrinol Metab 84: 90-97.

20. Morgenthaler NG. New assay systems for thyrotropin receptor antibodies. Curr Opin Endocrinol 1999; 6: 251-260.

21. Paunkovic N, Paunkovic J. Diagnostic Sensitivity of two Radio Receptor Assays (TRAKAssay and TRAK Dyno human) for detection of TSH receptor antibodies, Nuclear Medicine Review, 6 (2): 119-122, 2003.

22. Paunkovic N, Paunkovic J. Associated Graves' and Plummer' disease, Hellenic J of Nucl Med, 6(1): 44-47, 2003.

23. Anti TSHR antibodies to TSH-receptor, Elecsys and cobas e analyzers. Prospekt uz kit.

24. Božović B. Klinička endokrinologija, Beograd-Zagreb 1962, Medicinska knjiga. 